\title{
Socio-Economic Attributes of Residents of Slum and Shanty Areas of Lagos State, Nigeria
}

\author{
Yussuf Lukeman 1 \\ Bako, A.I ${ }^{2}$ \\ Omole, F.K ${ }^{*}$ \\ Nwokoro, I.I.C4 \\ Akinbogun, S.0 5 \\ 1and 4 Department of Urban and Regional Planning, University of Lagos \\ ${ }^{2}$ Department of Urban and Regional Planning, University of Ilorin \\ 3 Department of Urban and Regional Planning, Federal University of Technology, P.M.B 704Akure, Nigeria \\ *Email: fkyomole@yahoo.co.uk \\ ${ }^{5}$ Department of Estate Management, Federal University of Technology, Akure, Nigeria
}

\section{Doi:10.5901/mjss.2014.v5n9p656}

\section{Abstract}

The slum environment has come to stay in developing world of Africa, Latin America and Asia where the governments, nongovernmental organisations and international bodies have failed to properly manage the incessant activities of residents in some of the slum areas across the globe. In this paper, the socio-economic characteristic of residents in ljora-badia was investigated. Some of the socio-economic characteristics data were collected through questionnaires, personal interview, direct observation and focus group discussion. Some of the socio-economic attributes considered were marital status, education qualification, occupation/professional status, household income among others. The research population was based on the total number of the existing buildings from which the total numbers of household heads were determined and $5 \%$ of the total household head population was taken for the interview. The total number of 189 questionnaires were administered and responses were taken. Findings reveal that majority of the respondents which amounted to $30.2 \%$ were involved in petty trading which has direct effect on their daily income and standard of living. It is also discovered that the incomes of about $39.2 \%$ of the respondents are meager to cater for their immediate families; this makes the study area vulnerable to several criminal tendencies. The paper recommends that there should be synergy between the government and the residents of Badia by given them loan with no or little interest rate to boost their business in order to enhance their income and as well attend to their living environment.

Keywords: Urban slum, socio-economic, livelihood, poverty, ljora-Badia, Nigeria.

\section{Introduction}

One of the greatest challenges facing metropolitan Lagos is housing. The considerable gap between supply and demand has found expression in the astronomical cost of rented dwellings. Overcrowding, slums, and substandard housing are expressions of this problem. The aftermath of the shortfall in the housing stock has resulted in the urban slum being witnessed in Lagos state and Nigeria as a whole. The history of slum can be traced back to the era of industrial revolution and urbanization which was characterized by migration of people from rural areas to urban centres seeking a better means of livelihood because of the desire and anticipated opportunities at the urban centres. Formation of slum is not only limited to urbanization and industrial revolution, various researchers have argued that apart from urbanization, there are other factors responsible for slum formation in urban centres and these include inadequate provision of facilities, poor urban management and poverty (Adebayo, 1995).

Urban slum is an area of advanced blight condition usually requiring clearance or re-building as the most effective corrective action. It can also be said to be a poor, dirty area in urban area (Omole, 2000). Slums have also been seen as areas of social breakdown, high delinquency and that the residents are opponents of progress, lawless and lawbreakers (Omole and Owoeye, 2012). Some scholars are also of the view that the slum areas usually house and provid homes for 
the local migrants. This is so because migrants coming to the big cities may first settle in this part of the city where they have their relatives or perhaps they settle there because of the cost of accommodation which is relatively low, compared to other planned areas in the cities (Omole, 2000).

Global Urban Observatory (2003) reveals that slums excel in marginal or less valuable urban land such as riverbanks, steep slopes, dumping grounds, abandoned or unexploited plots, along transportation networks, near industrial areas and market places, and in low lying areas or wetlands. The main issue here is that the interests of the occupiers of such land are not protected by law which means that the interests are not secured against any government decision. Implicitly, slum can occur at the fringe or in the core. For proper identification of a slum area, the following yardstick or criteria can be useful as identified by (Chandramoulis, 2003) as area with dilapidated and infirm housing structures, poor ventilation, acute overcrowding, faulty alignment of streets, inadequate lighting, paucity of safe drinking water, logging during rains, absence of toilet facilities and non availability of basic physical and social services. The living conditions in slum are usually unhygienic and contrary to all norms of planned urban growth and venerable to all forms of pollutions and water borne disease. In view of these, this paper examines the socio-economic attributes of residents in ljora-Badia, Lagos, Nigeria which is an epitome of slum area as described above..

\section{The Study Area}

Lagos is regarded as a mega city, because its population is estimated to be about 18 million people, with a population density of 20,000 persons/sq km (Mabogunje, 2002). Lagos state is on a built-up land area of about 18,558 Hectares made up of about 9,669 hectares (52.1\%). residential, commercial, 1,021 hectares (5.5\%); industrial, 1,448 hectares (7.8\%); institutional and special areas, 2,784 hectares (14\%); transportation 3,340 hectares (18\%), and open spaces 52 hectares (2.8\%). The Lagos metropolis comprises 88.7 \% of Lagos state (Lagos State Economic Summit (2001).

The Lagos Metropolitan area with an area of 3557 square kilometers is defined as the continuous built-up area of Lagos, starting from the Atlantic Ocean in the south and spreading eastwards, westwards, and northwards. It includes eighteen of the twenty Local Government Areas of Lagos State and, another, four Local Government Areas of Ogun State. The vast territory of the Mega City is identified as covering 10 kilometers beyond the Lagos-Ogun State boundaries into Ogun State. The UN estimates that, with the present growth rate of Lagos State, the state will be the third largest mega city in the world by Year 2015 after Tokyo in Japan and Bombay in India. The rate of population growth is about 600,000 per annum with a population density of about 4,193 persons per sq. $\mathrm{km}$. In the built-up areas of Metropolitan Lagos, the average density is over 20,000 persons per square kilometers.

The study is set in ljora Badia one of the suburbs of Apapa Local Government area of Lagos State and it is located in the Southern fringe of the Lagos Metropolitan area. It is situated at the interaction point of the geographical latitude $3^{0}$ $23^{\prime}$ and longitude $4^{0} 22^{\prime}$. It is bounded in the North by the Lagos Badagry expressway link bridge into the National Theatre. A railroad to Apapa forms the Eastern boundary. The South is bounded by Ajegunle another low-income residential suburb.

\section{Literature Review}

Nwaka, (2005) pointed out the relationship between, the urban poor, the slum environment and the health policy in Nigeria. The World Health Organization (WHO) defines health as 'a state of complete physical, mental and social wellbeing and not merely the absence of disease or infirmity'. Such a state is conditioned by a variety of factors ranging from the genetic, the social and the emotional, to the natural and manmade environment. Consequently, consideration of such a state of health will have to take into account factors such as development objectives and strategies, and economic relations as well as the prevailing social structures, beliefs and value systems in the community. Of importance in this study is the socio-economic instability of the residents of this area

Poverty alleviation dominates the International Development Agenda of the $21^{\text {st }}$ century, and one of the primary concerns of the Millennium Development Goal is to urgently improve health and living conditions of the Millions of dwellers around the world (UN Habitat, 2003). Up to the 1980s, poverty was largely associated with the rural areas in developing countries; but the situation has changed with the dramatic increases in the numbers and proportion of the population living in the urban areas, and corresponding increase in the level of urban poverty. The ILO estimates that the proportion of the urban work force engaged in the informal sectors is highest in sub-Saharan Africa, and accounts for more than 50 percents of urban employment in two-thirds of the countries surveyed in 1999 (population report 2002).

These slum and irregular settlement have become so pervasive in Africa that they now outnumber legally planned development and their social legitimacy appears to be no longer in question; but the appalling environmental conditions 
associated with them constitute a major threat to the health and well-being of the urban community. The urban setting has many potentials health advantages because it reduces the unit cost of providing good quality of water supply, sanitation, drainage and preventive and curative health care; but without these essential prerequisites, concentrating people and their wastes in crowded slum would certainly increase health risk and spread of infections and parasitic disease. As the World Health Organization has emphasized, it is the home not the clinic that holds the key to a better health delivery system.

The main policy challenged Addressed by (Nwaka, 2005) which support and regulate the urban informal sector in a way that promotes shelter and livelihood for the poor, and at the same time ensures a safe, healthy and socially acceptable environment; how to ensure that the struggle against urban poverty and slum dwelling does not result in a campaign against urban poor and slum dwellers. (Nwaka, 2005) Examines how urban poverty and the informal city have developed in Nigeria over the last 50 years; the extent to which government policies and programs have helped or constrained the poor, and how these slums and irregular settlements can be upgraded and progressively integrated into the urban mainstream. It considers how housing and planning codes, standards and regulations inherited from the discriminatory policies and segregationist practices of the colonial period have continued to inhibit the access of the poor to affordable housing and tenure security; how the inadequate provision of water, sanitation and waste management has led to the spread of a wide variety of water-borne and filth-related disease such as diarrhea, typhoid and cholera; the various form of ill-health associated with malarial mosquitoes and other pests and diseases vectors; the problems of malnutrition and food contamination, especially in the fast growing street food catering industry; and the high incidence of respiratory infections among women and children, caused by indoor pollution from open cooking fires and stoves.

\section{Methodology}

This study focuses mainly on the socio-economic attributes of residents of ljora-Badia, Lagos State, Nigeria. The study embraces both primary and secondary sources of information. These were obtained from the field through the use of research instrument such as administration of questionnaires, personal interviews, observations and focus group discussion. Secondary information was collected from reports, (published and unpublished sources), textbooks, journals, file of government agencies and parastatals. These include the National Population Commission, The local government, and Internet, among many others.

There were 539 residential buildings in ljora-Badia, Lagos (Tenament Rate Department Apapa Local Government, 2011). It has an average of 7 households in a building, being a high residential area of metropolitan Lagos, which is in accordance with the National Population Commission (NPC) information of 2006. Since, the minimum average households per building is 7 households, the targeted population household in the study area translate to three thousand seven hundred and seventy three $(3,773)$ households (that is, $539 \times 7)$. The targeted household population of this study is 3,773 and the sample size is $5 \%$ of the targeted household population which translate to one hundred and eighty nine (189) and this becomes the total number of questionnaires administered for the study. In each of the districts in the study area, $5 \%$ sample size were considered reasonable for this study because of the homogeneous characteristics that was peculiar to the residents in the study area.

The research adopts multi-stage sampling technique in the research procedure.

First stage is the delineation and dividing ljora-Badia into three districts namely ljora Badia West, ljora Badia central, and ljora-Badia East (Onyeche, 2011).

Second stage is the identification of the buildings in each of the district by systematic sampling technique. All buildings in each district were arranged serially, from which the sampled buildings were selected. The $3^{\text {rd }}$ building forms the nth term while every $3^{\text {rd }}$ building was sampled from each district.

A randomly sampling technique was adopted in the third stage for the selection of household head sampled. This sampling method was based on household size in selected residential building. Household with highest number of people was selected.

Finally, in each of the districts, questionnaires were administered systematically and randomly selection of household head on every $3^{\text {rd }}$ buildings in each district. The questionnaires were administered according to the number of buildings in the study area. 
Table 1: Distribution of questionnaires within the districts in the study area.

\begin{tabular}{|l|c|c|}
\hline \multicolumn{1}{|c|}{ Name of districts } & Number of Buildings in each District & Number of Questionnaires Administered \\
\hline ljora-badia West & 129 buildings & 45 \\
\hline ljora-badia Central & 230 buildings & 81 \\
\hline ljora-badia East & 180 buildings & 63 \\
\hline Total & 539 Buildings & 189 \\
\hline
\end{tabular}

Source: Tenament rate department, Apapa Local Government. (2012)

\section{Research Findings}

The socio-economic variables considered in this study focus on the socio-economic attributes of residents in Badia Lagos Nigeria. The socio economic characteristics in the study area which comprises of gender, occupation, marital status, education qualification, household income per month, number of rooms occupied and years of living in the study area.

\subsection{Gender and Age of Respondents}

The gender of respondents as shown in table 2 reveals that $53.4 \%$ were male while $46.6 \%$ were female. It can be deduced that majority of respondents were male. The age of the respondents gives details on age characteristics in the study area. $23.3 \%$ of respondents' age fall within $20-29$ years, $39.7 \%$ of respondents' ages were within $30-39,10.1 \%$ of respondents were within the age range of $50-59$ years, $23.3 \%$ of respondents were within the age range of $40-49$ years and $3.7 \%$ of respondents were above 60 years. It can be inferred that majority of the respondents was within the age range 30-39years. This is a large number of people within the working age.

Table 2: Gender of respondents

\begin{tabular}{|c|c|c|}
\hline Sex & Frequency & Percentage \\
\hline Male & 101 & 53.4 \\
\hline Female & 88 & 46.6 \\
\hline Total & 189 & 100.0 \\
\hline
\end{tabular}

Source: Authors' Field Survey, 2012

Table 3: Age of respondents

\begin{tabular}{|c|c|c|}
\hline Age & Frequency & Percentage \\
\hline 20-29yrs & 44 & 23.3 \\
30-39yrs & 75 & 39.7 \\
40-49yrs & 44 & 23.3 \\
50-59yrs & 19 & 10.1 \\
above 60yrs & 7 & 3.7 \\
Total & 189 & 100.0 \\
\hline
\end{tabular}

Source: Authors' Field Survey, 2012

\subsection{Marital status and educational profiles of dwellers.}

The marital status indicated that $69.3 \%$ of respondents were married, $20.6 \%$ of the respondents wee single, $8.5 \%$ were widow/widower and $1.6 \%$ of respondents were divorced (table 4). The result here simply shows that most of the respondents in the study area were married.

The education/ qualification of respondents in the study area as shown in table 5 reveals that $14.3 \%$ of respondents have no formal education, $19.0 \%$ have primary education, $49.7 \%$ have secondary education and $16.9 \%$ of respondents have tertiary education. It can be deduced that majority of the respondents in the study area were secondary school certificate holders. This has significant effect on the level of literacy in the study area and the way they perceive their environment. 
Table 4: Marital status of respondents

\begin{tabular}{|l|c|c|}
\hline Marital Status & Frequency & Percentage \\
\hline Married & 131 & 69.3 \\
Single & 39 & 20.6 \\
Widow/Widower & 16 & 8.5 \\
divorced & 3 & 1.6 \\
Total & 189 & 100.0 \\
\hline
\end{tabular}

Source: Authors' Field Survey, 2012

Table 5: Education qualification

\begin{tabular}{|l|c|c|}
\hline Education & Frequency & Percentage \\
\hline No formal education & 27 & 14.3 \\
Primary & 36 & 19.0 \\
Secondary & 94 & 49.7 \\
Tertiary & 32 & 16.9 \\
Total & 189 & 100.0 \\
\hline
\end{tabular}

Source: Authors' Field Survey, 2012

\subsection{Occupation and house hold income.}

The occupation/professional status of respondents in the study area as shown in table 6 indicates that, 14.3\% of respondents were civil servant, $23.3 \%$ of were businessman/businesswomen, $23.3 \%$ were artisan, $30.2 \%$ were involved in petty trading, $2.6 \%$ were retired and $6.3 \%$ were unemployed. The result here clearly shows that relatively a large number of the respondents were involved in petty trading which has direct effect on their daily income and standard of living. This further explains the level of poverty in this area.

The household income per month of the respondents show that the income varied from 10,000 Naira to 80,000 Naira, $39.2 \%$ of respondents' income were less than $\$ 18,000,32.3 \%$ of respondents' income ranges from $\# 19,000$ $30,000,21.2 \%$ were within the range of $31,000-40,000,3.2 \%$ were within the range of $41,000-50,000,3.7 \%$ within $51,000-60,000$ and only $0.5 \%$ of respondents were above $\mathrm{A} 80,000$. One can infer here that the incomes of majority of the respondents were meager in catering for their immediate families. This makes the study area vulnerable to several criminal tendencies and perhaps the major causes of poverty in this area.

Table 6: Occupation/Professional Status

\begin{tabular}{|l|c|c|}
\hline Occupation/Professional Status & Frequency & Percentage \\
\hline Civil servant & 27 & 14.3 \\
Businessmen/Businesswomen & 44 & 23.3 \\
Artisan & 44 & 23.3 \\
Petty trader & 57 & 30.2 \\
Retired & 5 & 2.6 \\
Others & 12 & 6.3 \\
Total & 189 & 100.0 \\
\hline
\end{tabular}

Source: Authors' Field Survey, 2012

Table 7: Household income per month

\begin{tabular}{|c|c|c|}
\hline Monthly Income & Frequency & Percentage \\
\hline$>18,000$ & 74 & 39.2 \\
$19,000-30,000$ & 61 & 32.3 \\
$31,000-40,000$ & 40 & 21.2 \\
$41,000-50,000$ & 6 & 3.2 \\
$51,000-60,000$ & 7 & 3.7 \\
80,000 above & 1 & .5 \\
Total & 189 & 100.0 \\
\hline
\end{tabular}

Source: Authors' Field Survey, 2012

Naira $(\mathrm{N})=$ Nigeria Currency, 1 Naira $=175$ US Dollars as at the line of this reseach. This is street exchange rate. 


\subsection{Rooms occupancy and length of stay in the area.}

The numbers of room occupied by respondents in the study area as shown on table 8 reveals that $75.7 \%$ of dwellers occupied single room. $22.8 \%$ occupied two rooms and $1.6 \%$ occupied three rooms. This may have effect on the health conditions of respondents as the highest percentage of respondents were living in a room, which may be responsible for high spread of diseases, for example, tuberculosis, and diarhorrea.

The years of living in the study area by respondents indicated that $35.4 \%$ of respondents have spent less than 10 years, $41.3 \%$ have spent between $11-20$ years, $13.8 \%$ have spent between $21-30$ years, $6.9 \%$ between $31-40$ years and $2.5 \%$ have spent between $41-50$ years. This means that migration of people to slum environment is very rampant in the past twenty years because of the cheap accommodation.

Table 8: Numbers of room occupied

\begin{tabular}{|c|c|c|}
\hline Options & Frequency & Percentage \\
\hline One & 143 & 75.7 \\
Two & 43 & 22.8 \\
Three & 3 & 1.6 \\
Total & 189 & 100.0 \\
\hline
\end{tabular}

Source: Authors' Field Survey, 2012

Table 9: Years of living in the study area

\begin{tabular}{|l|c|c|}
\hline Options & Frequency & Percentage \\
\hline Less than 10 yrs & 67 & 35.4 \\
11-20yrs & 78 & 41.3 \\
21-30yrs & 26 & 13.8 \\
31-40yrs & 13 & 6.9 \\
41-50yrs & 5 & 2.6 \\
Total & 189 & 100.0 \\
\hline
\end{tabular}

Source: Authors' Field Survey, 2012

\section{Recommendations and Policy Guidelines}

This study has identified socio-economic characteristics of residents in slums and shanty dwellers in Nigeria as epitomized in ljora Badia. The following are some of the policy recommendations of this study.

$>$ There should be synergy between the government and the residents of Badia by given them loan with no or little interest to boost their business in order to enhance their monthly income and thereby invest on their living environment.

> The government should establish vocational training centres at strategic place in Badia in order to enhance the semi skilled labour force in the study area and also generate more employment opportunities.

$>$ There should be enlightenment campaign and people oriented awareness about the importance of habitable environment, and maintenance culture of social facilities provided by the government.

$>$ The government at all level (federal, state and local) should develop the surrounding rural area in order to reduce the rural-urban migration that was found to be one of the causes of migration to this area.

$>$ Government should establish more primary and secondary schools and of cause adult education centres in the study area which could serve as way of encouraging the residents to improve their education and thereby improve their environment..

\section{References}

Adebayo, O. (1995): The Slum Development in Developing Countries Retrieved from http//www.UN Habitat on human settlement on 02/04/2011 at 10.23AM

Chandramoulis, C.(2003): Slum in Chiennai: A profile in Martins J. Bunch, V. Madha Suresh and T. Vasantha Kumaran (eds) Proceedings of the third International Conferences on Environment and Health, Chiennai India, 15-17 Dec, 2003. Retrieved from $\mathrm{http} / \mathrm{www}$.slum of the millennium-development on 13/05/2011 at 1.10am 
Mabogunje, A.L (2002): National Housing and Urban Development Policy: Catalyst for Mass Housing Delivery in Nigeria; Lead Paper Presented at the Second Abuja International Housing Summit Held at the Le Meridien Hotel Abuja.

National Population Commission (2006): Census Report in Nigeria. Collected in Lagos State NPC Office Surulere.

National Population Commission official web site. http//www.npcnigeria.org

Nwaka, G.I (2005): The Urban Informal Sector in Nigeria towards Economic Development Environmental Health and Social Harmony. Journal of Global Urban Development (1.) 14-17

Nwaka, G.I (2005): The Urban Poor, The Informal City and Environmental Health Policy in Nigeria. Journal of Global Urban Development. 2 ( 2) 5-7

Omole, F.K (2000): Urban Decay in Nigerian Cities: Analysis of Problems and Renewal Strategies. International Journal of Urban and Regional Affairs. 4(3): 20-30.

Omole, F. K. and Owoeye, J. O. (2011): Slum Characteristics of a Deplorable Residential District of Akure, Nigeria. Journal of the Environment, Federal University of Technology, Yola. 6(2): 94-103

Onyeche, .E (2011): Ijora Badia: Slum for decades" Unpublished Article Retrieved from http//www.slumnigeria.org on 17/6/2011

Tenament Rate Department, (2011): Apapa Local Government Apapa Lagos State.

UN-HABITAT, Global Urban Observatory (2003): Guide to Monitoring Target 11: Improving The Lives of 100 Million Slum Dwellers. Nairobi: UN-HABITAT, 2003. Retrieved from http://www.unhabitat.org on 13/04/2011 at 12.10pm

UN-HABITAT, (2011): Population Report in Developing Countries. Retrieved from http//www.unhabitat.org on 04/07/2011 at 12.05pm

United Nations Population Division: World Urbanization Prospects: the 2003 Revision. New York: United Nations, 2003. Retrieved from http//www.unhabitat.org on 02/06/2011 at 1.05am

US AID, (1987): Accent for Health: Living Proof of Progress. Horizons. Spring, 1987. Retrieved from http//www.usaid.gov on 4/5/2011 at 6.30pm.

WHO, (1987): Housing and Health: An Agenda for Action Geneva, WHO. Retrieved from http//www.who.org on 2/03/2011 at 11.30pm. 